\title{
Aqueous Extract of Cornsilk Confers Mild Diuretic Activity in Normal Rats
} (Ekstrak Akues Sutera Jagung Cetus Aktiviti Diuretik Sederhana dalam Tikus Normal)

\author{
M.A. SOliHAH, A.R. NURHANAN, W.A. WAN AmIR NiZAM \& W.I. WAN RosLI*
}

\begin{abstract}
Cornsilk is traditionally used to treat illnesses related to kidney and as diuretic agent. The study was performed to evaluate the effectiveness of Malaysian cornsilk in elevating diuresis and their dose response relationship in normal Sprague-Dawley rat. The diuresis activity was determined by administered the rats with different dose treatments of 400, 500, 600, 700 and $800 \mathrm{mg} / \mathrm{kg}$. Cumulative urine was significantly increased with the dosage levels (400-600 mg/ $\mathrm{kg}$ ) ranging from $14.06-20.13 \mathrm{~mL}$. Cumulative urine of aqueous extract of cornsilk (AEC) at $400 \mathrm{mg} / \mathrm{kg}(14.06 \mathrm{~mL})$ and $500 \mathrm{mg} / \mathrm{kg}(15.21 \mathrm{~mL})$ treatments found to be significantly lower than positive control $(21.25 \mathrm{~mL})$. In addition, Na content was significantly higher compared with negative control at dosages of 500, 600, 700 and $800 \mathrm{mg} / \mathrm{kg}$. At any rate, $\mathrm{K}^{+}$and $\mathrm{Cl}^{-}$content of all AEC treatments were not significantly different during $24 \mathrm{~h}$ monitoring. The $\mathrm{pH}$ values were increased paralleled with the increment of AEC dosages, though it was not significant. On the other result, the ED of AEC was observed at $454.10 \mathrm{mg} / \mathrm{kg}$. Malaysian AEC had shown a mild diuretic activity in elevating urine and $\mathrm{Na}^{+}$ content at dosages from 500 to $800 \mathrm{mg} / \mathrm{kg}$. Whilst, AEC also showed an effect of potassium sparing diuretics. Thus, it is suggested that Malaysian cornsilk can be used as an alternative natural diuretic agent.
\end{abstract}

Keywords: Aqueous extract; cornsilk; diuretic property

\section{ABSTRAK}

Sutera jagung kerap kali digunakan secara tradisi untuk merawat masalah kesihatan yang berkaitan dengan buah pinggang dan sebagai agen diuretik. Kajian telah dilakukan untuk menilai keberkesanan sutera jagung Malaysia dalam meningkatkan diuresis dan perkaitan respons dos dalam tikus Sprague-Dawley normal. Aktiviti diuresis telah ditentukan dengan memberi rawatan kepada tikus pada dos yang berbeza (7 kumpulan/6 ekor setiap kumpulan) iaitu 400, 500, 600, 700 dan $800 \mathrm{mg} / \mathrm{kg}$. Air suling digunakan sebagai kawalan negatif manakala hidroklorothiazid pula sebagai kawalan positif. Keputusan kajian menunjukkan urin kumulatif meningkat secara signifikan dengan peningkatan dos (400-600 mg/ $\mathrm{kg}$ ) dalam julat daripada 14.06-20.13 mL. Urin kumulatif ekstrak akues sutera jagung (AEC) pada dos 400 (14.06 mL) dan $500 \mathrm{mg} / \mathrm{kg}(15.21 \mathrm{~mL})$ didapati lebih rendah daripada kawalan positif $(21.25 \mathrm{~mL})$. Sebagai tambahan, kandungan $\mathrm{Na}^{+}$ adalah lebih tinggi secara signifikan berbanding kawalan negatif pada dos 500, 600, 700 dan $800 \mathrm{mg} / \mathrm{kg}$. Pada semua kadar, kandungan $\mathrm{K}^{+}$dan $\mathrm{Cl}^{-}$bagi semua perlakuan AEC adalah tidak signifikan dalam masa 24 jam pemerhatian. Nilai pH meningkat selari dengan peningkatan dos AEC, walaupun tidak signifikan. Dalam keputusan lain, $\mathrm{ED}_{50}$ AEC adalah sebanyak $454.10 \mathrm{mg} / \mathrm{kg}$. AEC Malaysia telah menunjukkan aktiviti diuretik sederhana dalam meningkatkan kandungan urin dan $\mathrm{Na}^{+}$pada dos 500 hing ga $800 \mathrm{mg} / \mathrm{kg}$. Sementara itu, AEC juga menunjukkan kesan penahanan diuretik kalium. Oleh itu, sutera jagung Malaysia dicadangkan boleh digunakan sebagai agen diuretik semula jadi.

Kata kunci: Ekstrak akues; sifat diuretik; sutera jagung

\section{INTRODUCTION}

Natural plant has been used for centuries as a folk medicine to treat various illnesses. Many people presume natural plant safer than normal drug used to treat certain diseases. This situation has triggers scientist interest in investigating further the benefits of natural plant as an alternative remedies. Corn is one of the food item commonly consumed in Malaysia. Unfortunately, by-product of corn cob namely cornsilk which is popular as a traditional medicine amongst North Americans, Chinese and Indians is discarded upon harvesting of corn. Therefore, an effort is taken to investigate the possibility of Malaysian cornsilk as a therapeutic agent to treat diuresis.
Cornsilk is from Zea mays (Gramineae) family. It is found inside the husk and hardly reveals until the emergence of yellow pale silk at the end of the husk. Cornsilk has been reported to have antioxidant properties (Ebrahimzadeh et al. 2008; El-Ghorab et al. 2007; Eman 2011; Liu et al. 2011), antiprostatitis and antispasmodic (Buhner 2007). In addition, cornsilk is well known to treat infection and cystitis (Steenkamp 2003), help pass stone from kidney and others related to renal illness (Maksimovic et al. 2005). Cornsilk was reported to contain sitosterol, stigmasterol, fatty and volatile oil, saponin, glucoside substance and vitamin C and K (Bobryshev 1962). In previous study, cornsilk was also reported to consist 
of saponin, terpenoid, glycoside, alkaloid, tannin and phlobatannin, flavonoids and phenol.

Herbs are common ingredient used as food flavouring over hundreds of years and generally regarded as natural remedies for certain particular diseases. Herbs and botanicals interest as a health benefits amongst consumers is on the rise (Foote \& Coohen 1998). In recent years, food manufacturers have focused their products with health benefits using herbs or botanicals as their key ingredients. In the food industries, it is commonly known as functional food or products which have an add-on value to the products. However, approximately $80 \%$ of world's population consistently rely on plants for health promote and remedial (Esiyok et al. 2004). Instead of relying on a modern treatment, peoples are harmonizing natural products to gain a complete recuperation.

Since cornsilk is popular in treated diseases related to renal, it leads us to investigate the diuretic activity of Malaysian's cornsilk. Even though many researchers have been done on the diuretic activity of cornsilk, but there were different variations conclusion observed among researchers. Habitually, there is variability of phytochemicals amongst plants namely genotype, size and maturity, soil conditions, fertilization, irrigation, pesticide utilization, disease and pests, location and climate and season (Xin et al. 2006). Furthermore, cornsilk is rarely known used as traditional medicines among Malaysian population. Therefore, the aimed of the present study was to evaluate the diuretic activity of Malaysian cornsilk and the dose response relationship of its aqueous extract.

\section{MATERIALS AND METHODS}

\section{DRUGS}

Hydrochlorothiazide is supplied by the Department of Pharmacy of Hospital Universiti Sains Malaysia. This drug is used as reference diuretic agents.

\section{PLANT MATERIAL}

Corn fruit was bought from Pasar Siti Khatijah wet market located in Kota Bharu town, Kelantan, Malaysia. Cornsilk was then detached from corn fruit and the inside tassel was collected. Cornsilk was dried at $55^{\circ} \mathrm{C}$ in air oven overnight until golden yellowish colours of cornsilk were achieved. Dried cornsilk was ground and formed into powder used domestic blender (National; MX-895).

\section{PREPARATION OF EXTRACTS}

Aqueous extract was prepared by boiling $80 \mathrm{~g}$ of cornsilk powder with distilled water for $30 \mathrm{~min}$. The ratio of cornsilk to distilled water used was 1:15 (w/v). The solution was then filtered through Advantec filter paper (No. 1) attached to the vacuum pump (Welch; 2545C-02) at $30-40 \mathrm{kPa}$. The filtrate was then heated on hot plate with temperature below $60^{\circ} \mathrm{C}$ until it completely concentrated.
This concentrated extract was used to prepare different dosages of aqueous extract of cornsilk (AEC) at 400, 500, 600 and $700 \mathrm{mg} / \mathrm{kg}$.

\section{EXPERIMENTAL ANIMALS}

Sprague Dawley (SD) male adults weight ranged between 250-300 g were used in the experiments and treated according to the ethical guideline set by animal ethic committee of Universiti Sains Malaysia (USM/Animal Ethics Approval/2009/(48)(153)). The animals were grouped in the cage of five, with $12 \mathrm{~h}$ light dark cycle and placed in Animal Research and Service Centre (ARASC) of USM. The animal was fed with a balanced pellet diet and tap water was administered ad libitum. Prior to the start of experiment all animals was placed in metabolic cage individually and fasted overnight with free access to water. Total of $25 \mathrm{~mL} / \mathrm{kg}$ body weight (BW) of aqueous extract of cornsilk (AEC) with different dosages of 400, 500,600 and $700 \mathrm{mg} / \mathrm{kg}$ were given orally to each rat as shown in Table 1. Each solution was prepared freshly prior to administration. The care and handling of rats were in accordance of standard guidelines for laboratory animal use and care.

\section{ELECTROLYTE CONTENTS IN AEC}

An aqueous extract were dissolved in distilled water. The contents of sodium, potassium and chloride in $\mathrm{mmol} / \mathrm{L}$ were measured using ion photometer.

\section{DIURETIC STUDY}

The modified method of Arafat et al. (2008) was used to determine the diuretic effect. The morning after have been fasted overnight, the rats were given orally, $25 \mathrm{~mL} / \mathrm{kg}$ of treatment solution and then were placed in each metabolic cage. Urine excreted for the next $24 \mathrm{~h}$ were collected. The volume and $\mathrm{pH}$ of each rat were measured and then kept under $-18^{\circ} \mathrm{C}$ prior to other analysis. Electrolyte content of sodium, potassium and chloride in AEC were determined by ion selective electrodes (Architect C8000 Analyzer). Osmolality of urine were determined by osmometer (Osmomat, 030).

\section{REPEATED ADMINISTRATION OF AEC}

The rats were administered with the same dose of AEC as day 1 for another 4 days. The similar parameters as day 1 are observed.

\section{STATISTICAL ANALYSIS}

All results were presented as mean \pm S.E.M (standard error of means). Statistical significant differences between groups were evaluated by one-way analysis of variance (ANOVA). The $p$ value less than 0.05 were used to represent significant differences. 
TABLE 1. Effect of diuretic activity produced by different treatment groups

\begin{tabular}{lccccc}
\hline Treatment & $\begin{array}{c}\text { Cumulative urine } \\
\text { volume }(\mathrm{mL} / 24 \mathrm{~h})\end{array}$ & Diuretic index $^{\mathrm{a}}$ & Diuretic activity $^{\mathrm{b}}$ & $\mathrm{pH}$ & Osmolality \\
\hline Distilled water & $14.94 \pm 0.27^{+}$ & 1.00 & 0.70 & $8.24 \pm 0.08$ & $1598.50 \pm 73.32$ \\
Chlorotiazide $(10 \mathrm{mg} / \mathrm{kg})$ & $21.25 \pm 1.14^{*}$ & 1.42 & 1.00 & $8.28 \pm 0.22$ & $1254.00 \pm 111.93$ \\
$400 \mathrm{mg} / \mathrm{kg} \mathrm{AEC}$ & $14.06 \pm 0.37^{+}$ & 0.94 & 0.66 & $8.20 \pm 0.12$ & $1568.00 \pm 8.00$ \\
$500 \mathrm{mg} / \mathrm{kg} \mathrm{AEC}$ & $15.21 \pm 0.96^{+}$ & 1.09 & 0.76 & $8.31 \pm 0.20$ & $1488.00 \pm 149.95$ \\
$600 \mathrm{mg} / \mathrm{kg} \mathrm{AEC}$ & $20.13 \pm 0.61^{*}$ & 1.35 & 0.94 & $8.41 \pm 0.24$ & $1456.88 \pm 77.29$ \\
$700 \mathrm{mg} / \mathrm{kg} \mathrm{AEC}$ & $19.63 \pm 0.53^{*}$ & 1.31 & 0.92 & $8.81 \pm 0.19$ & $1509.13 \pm 45.10$ \\
$800 \mathrm{mg} / \mathrm{kh} \mathrm{AEC}$ & $20.00 \pm 0.58^{*}$ & 1.34 & 0.94 & $8.33 \pm 0.17$ & $1548.00 \pm 45.54$ \\
\hline
\end{tabular}

The results showed the mean values and standard errors of measurements $(n=8)$ in each groups. One-way ANOVA was applied followed by post hoc comparison. The differences in each column show as; $* p<0.05$ with respect to distilled water,

${ }^{+} p<0.05$ with respect to chlorothiazide (positive control). ${ }^{a}$ Diuretic index $=$ (cumulative urine volume of treated group)/ (cumulative urine volume of control group).

${ }^{b}$ Diuretic activity $=$ diuretic index of treated test extract/diuretic index of standard drug

\section{RESULTS}

\section{PLANT EXTRACT}

AEC yield obtained was $40.8 \%$. There was a report on phytochemicals found in cornsilk contains of flavonoids, saponin, tannins, phlobatannins, phenols, alkaloids and cardiac glycosides (Solihah \& Wan Rosli 2012).

\section{ELECTROLYTE CONTENTS IN AEC}

The amount of sodium, potassium and chloride in $10 \mathrm{mg} /$ $\mathrm{mL}$ of AEC are illustrated in Figure 1. The sodium level found was $20 \mathrm{mmol} / \mathrm{L}$. Meanwhile the potassium and chloride content were 28 and $16 \mathrm{mmol} / \mathrm{L}$, respectively.

\section{VOLUME, PH AND OSMOLALITY OF URINE EXCRETED}

The cumulative urine collected during $24 \mathrm{~h}$ showed significant differences between AEC treatments to distilled water and chlorothiazide group (Table 2). The urine excretion that received AEC doses at 600,700 and $800 \mathrm{mg} /$ $\mathrm{kg}$ were significantly higher compared to distilled water. Meanwhile in comparison to chlorothiazide, AEC dose at 400 and $500 \mathrm{mg} / \mathrm{kg}$ seemed to be statistically lower. Therefore, the urine amount of AEC dosage at 600 and 700 were not statistically significant to chlorothiazide. Immensely doses of 600,700 and $800 \mathrm{mg} / \mathrm{kg}$ are equally effective to excrete urine at same rate with $10 \mathrm{mg} / \mathrm{kg}$ of

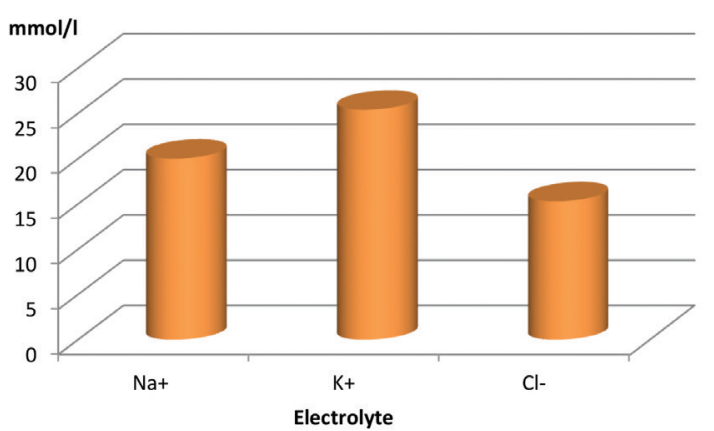

FIGURE 1. Electrolyte content of AEC in $10 \mathrm{mg} / \mathrm{mL}$

chlorothiazide. Above of all, the maximum urine excreted of AEC dose monitored at $600 \mathrm{mg} / \mathrm{kg}$ and became faintly stagnant at dose of 700 and $800 \mathrm{mg} / \mathrm{kg}$. Diuretic index of AEC ranged from 0.94 to 1.35 , meanwhile diuretic activity ranged from 0.66 to 0.94 (Table 2). Diuretic activity is a good indicator for the efficacy. From the table, AEC doses at 600,700 to $800 \mathrm{mg} / \mathrm{kg}(0.94,0.92$ and 0.94$)$ have a good efficacy for diuretic activity when compared to hydrochlorothiazide (1.00). Other than that, the urinary $\mathrm{pH}$ showed no significant difference with respect to distilled water. However, urinary $\mathrm{pH}$ for AEC treatment at doses 600 and $700 \mathrm{mg} / \mathrm{kg}$ were slightly higher from distilled water.

TABLE 2 . The electrolytes content of urine after $24 \mathrm{~h}$ administered with AEC

\begin{tabular}{|c|c|c|c|c|c|c|c|}
\hline & \multirow{2}{*}{$\mathrm{Na}^{+}$} & \multirow{2}{*}{$\mathrm{K}^{+}$} & \multirow{2}{*}{$\mathrm{Cl}^{-}$} & \multicolumn{3}{|c|}{ Saliuretic index ${ }^{a}$} & \multirow{2}{*}{$\mathrm{Na}^{+} / \mathrm{Cl}^{-}$} \\
\hline & & & & $\mathrm{Na}^{+}$ & $\mathrm{K}^{+}$ & $\mathrm{Cl}^{-}$ & \\
\hline Distilled water & $40.63 \pm 4.12^{+}$ & $246.25 \pm 10.79$ & $86.38 \pm 2.79$ & 1.00 & 1.00 & 1.00 & 0.47 \\
\hline Chlorotiazide (10 mg/kg) & $90.38 \pm 4.16^{*}$ & $243.75 \pm 7.91$ & $104.62 \pm 4.20$ & 2.22 & 0.99 & 1.21 & 0.86 \\
\hline $400 \mathrm{mg} / \mathrm{kg}$ AEC & $52.13 \pm 2.49^{+}$ & $258.38 \pm 5.64$ & $89.38 \pm 6.72$ & 1.28 & 1.05 & 1.03 & 0.58 \\
\hline $500 \mathrm{mg} / \mathrm{kg}$ AEC & $62.75 \pm 3.60^{*+}$ & $255.00 \pm 8.28$ & $110.12 \pm 8.66$ & 1.60 & 1.04 & 1.27 & 0.57 \\
\hline $600 \mathrm{mg} / \mathrm{kg} \mathrm{AEC}$ & $63.50 \pm 1.79^{*+}$ & $224.12 \pm 10.69$ & $83.38 \pm 4.78$ & 1.56 & 0.91 & 0.97 & 0.76 \\
\hline $700 \mathrm{mg} / \mathrm{kg}$ AEC & $58.67 \pm 3.74^{*+}$ & $232.87 \pm 5.46$ & $79.50 \pm 6.16$ & 1.24 & 0.95 & 0.92 & 0.63 \\
\hline $800 \mathrm{mg} / \mathrm{kg}$ AEC & $62.33 \pm 3.28^{*+}$ & $236.60 \pm 18.75$ & $107.7 \pm 8.29$ & 1.53 & 0.96 & 1.25 & 0.58 \\
\hline
\end{tabular}

The results showed the mean values and standard errors; $(n=8)$ in each groups. Statistical analyses used are one-way ANOVA followed by post hoc comparison. The differences in each column show as; ${ }^{*} p<0.05$ with respect to distilled water and ${ }^{+} p<0.05$ with respect to chlorothiazide.

${ }^{a}$ Saliuretic index $=$ problem group $(\mathrm{mmol} / \mathrm{L}) / \operatorname{control}$ group $(\mathrm{mmol} / \mathrm{L})$ 


\section{EFFECT ON URINARY ELECTROLYTE EXCRETION}

The urinary $\mathrm{Na}^{+}$excretion found among AEC doses are significantly higher compared with distilled water (40.63 mmol/L), except AEC at dose of $400 \mathrm{mg} / \mathrm{kg}$ (52.13 $\mathrm{mmol} / \mathrm{L})$. However, all AEC doses ranging from 400 to $800 \mathrm{mg} / \mathrm{kg}$ are significantly lower when compared with hydrochlorothiazide $(90.38 \mathrm{mmol} / \mathrm{L})$. On the other part, $\mathrm{K}^{+}$excretions of all AEC doses are not significantly differed from distilled water or hydrochlorothiazide except during dose of 600 and $700 \mathrm{mg} / \mathrm{kg}$ which are significantly lower compared with hydrochlorothiazide. Furthermore, $\mathrm{Cl}^{-}$excretion found no statistical different between AEC group and both control groups. The saliuretic index of $\mathrm{Na}+$ is higher in all extracts compared with control group. Meanwhile, $\mathrm{K}+$ and $\mathrm{Cl}$ - found to be lower in all extract than the control group. On the other part, all AEC doses have an increased of $\mathrm{Na}^{+} / \mathrm{Cl}^{-}$ratio when comparison made to control group. Nevertheless, all ratios are lower than chlorothiazide (0.86) treatment.

\section{MEDIAN EFFECTIVE DOSE OF AEC DIURESIS}

During $24 \mathrm{~h}$ observation, the AEC showed a significant dose dependant diuretic activity in terms of cumulative urine excreted (Figure 2). The present study indicated that there is no significant increased at doses of 100, 200 and 300 $\mathrm{mg} / \mathrm{kg}$ of AEC (unpublished data) and so at a dose of 400 $\mathrm{mg} / \mathrm{kg}(14.06 \pm 0.37 \mathrm{~mL})$. The effect of diuresis started to increase at a dose of $500 \mathrm{mg} / \mathrm{kg}(15.21 \pm 0.96 \mathrm{~mL})$ and 600 $\mathrm{mg} / \mathrm{kg}(20.13 \pm 0.61 \mathrm{~mL})$. Later, it becomes plateau at dose of $700 \mathrm{mg} / \mathrm{kg}(19.63 \pm 0.53 \mathrm{~mL})$ and $800(20.00 \pm 0.58 \mathrm{~mL})$. From this observation, the AEC shows a pharmacological effect of median effective dose $\left(\mathrm{pED}_{50}\right)$ at $454.10 \mathrm{mg} /$ $\mathrm{kg}$, as illustrated in Figure 2. The maximum effect of the diuresis was observed at $20.93 \pm 6.65 \mathrm{~mL}$, while the baseline at $11.02 \pm 5.26 \mathrm{~mL}$.

\section{EFFECT OF REPEATED ADMINISTRATION OF AEC ON URINE EXCRETED}

A repeated exposure of AEC at dose of 400, 500, 600, 700 and $800 \mathrm{mg} / \mathrm{kg}$ during 5 consecutive days showed no statistical difference in cumulative urine, $\mathrm{pH}$, osmolality, sodium, potassium and chloride when compared with day 1 of respective group (Figure 3 ).

\section{DISCUSSION}

Diuretics are synthetic drug which is used to increase the volume of urine excreted from body. This is the first study to demonstrate the diuretic activity of Malaysian cornsilk. Apart from that, Wright et al. (2007) has wind up about 19 plants to show the potential diuretic effects. Diuretics have a wide definition and commonly referred as excretion of water and $\mathrm{Na}^{+}$in larger volume (Rang et al. 2007). Whereas diuresis commonly known as a process to increase the formation of urine. In the present study, AEC was seemed to be able to present as mild diuretics as it is capable to increase urine and $\mathrm{Na}^{+}$excretion. The electrolytes content in the AEC extract showed that $\mathrm{Na}^{+}(20.0 \mathrm{mmol} / \mathrm{L})$ has lower value compared with $\mathrm{K}^{+}(28.0 \mathrm{mmol} / \mathrm{L})$, while $\mathrm{Cl}$ - is the lowest with $16.0 \mathrm{mmol} / \mathrm{L}$ in every $10 \mathrm{mg} / \mathrm{mL}$. These results are lower compared to Erica multiflora and Cyanadon dactylon which have been reported by Sadki et al. (2010). Erica multiflora contained 33.9 and 25.8 $\mathrm{mmol} / \mathrm{L}$ of $\mathrm{Na}^{+}$and $\mathrm{K}^{+}$while Cyanodon dactylon contained 75.26 and $56.77 \mathrm{mmol} / \mathrm{L}$ of $\mathrm{Na}^{+}$and $\mathrm{K}^{+}$, that was much higher compared with Erica multiflora. The electrolytes content of both plants have been converted into $\mathrm{mmol} / \mathrm{L}$, so that relative comparison can be done.

On the other part, AEC treatment did not have significant differences among all electrolyte excretion except for sodium content at doses of 500 and $600 \mathrm{mg} / \mathrm{kg}$ in comparison to control group $(40.63 \pm 4.12 \mathrm{mmol} / \mathrm{L})$. In

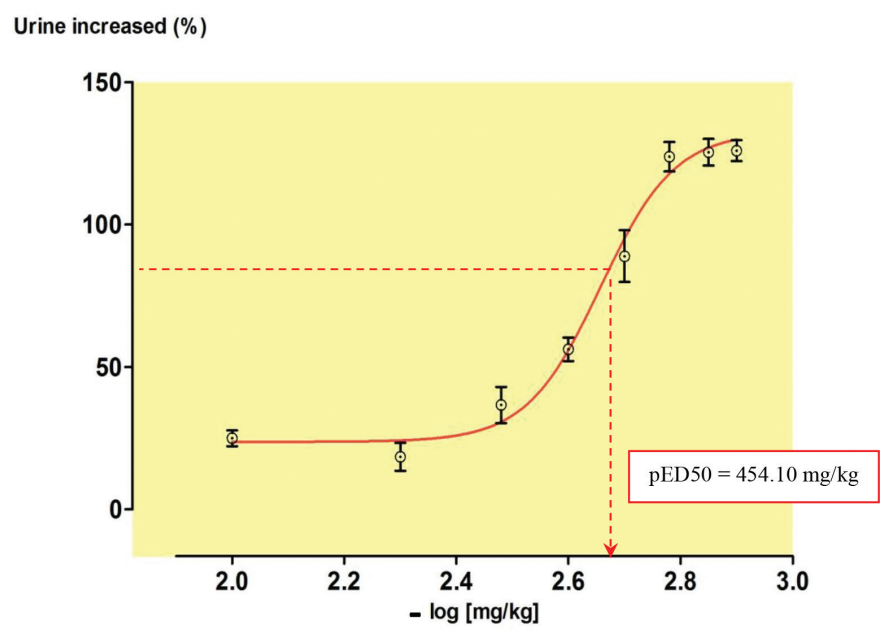

FIGURE 2. Log concentration-dose response curve of urine increased $(n=6)$ generated using Graphpad Prism. Volume at baseline was $11.02 \pm 5.26 \mathrm{~mL}$ 


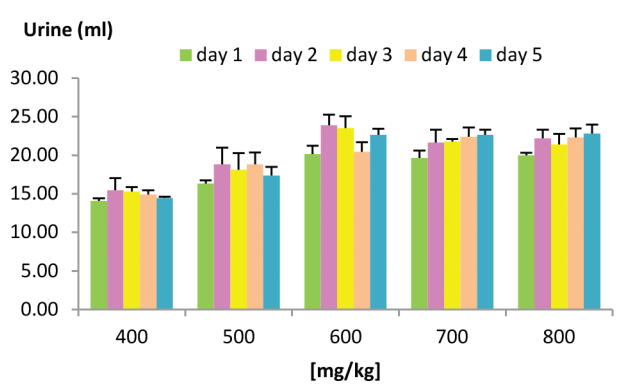

(a)

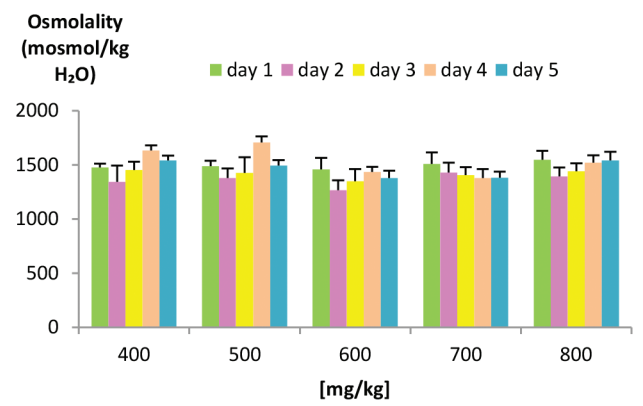

(c)

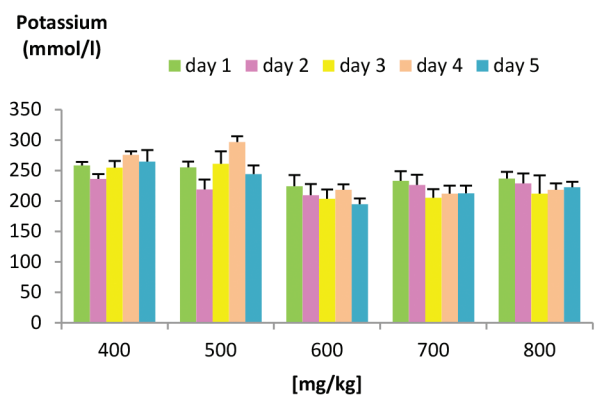

(e)

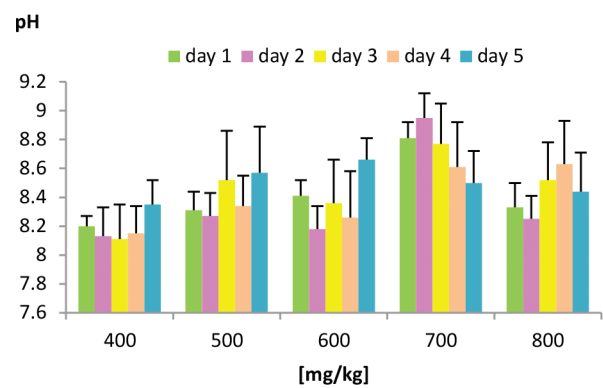

(b)

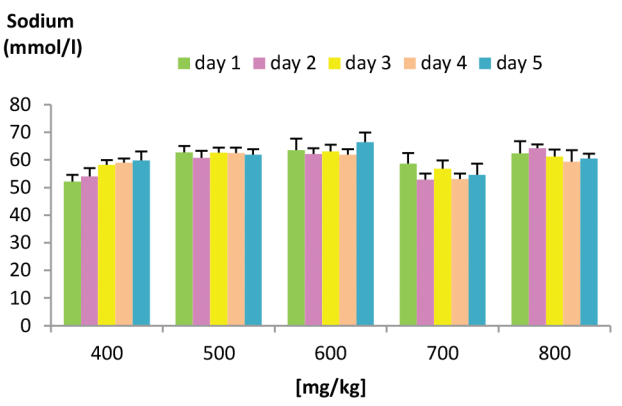

(d)

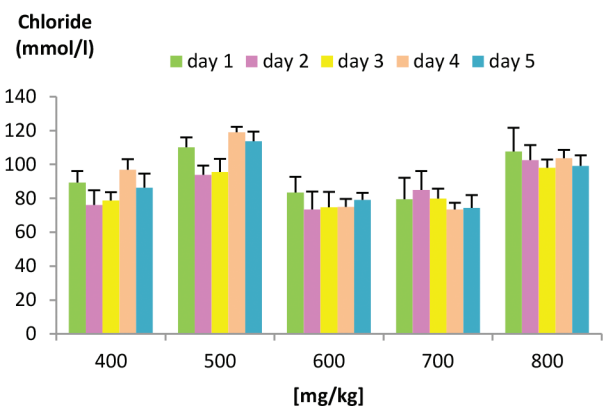

(f)

FIGURE 3. Effect of repeated oral administration of CAE on urine excretion (a), pH (b), osmolality (c), sodium (d), potassium (e) and chloride (f). Day of treatment was subjected to 5 days. The urine samples were collected daily. Each bar represents the mean of 6 animals and vertical lines indicated the S.E.M. Asterisks denote the level of significant in comparison to day 1 using one-way ANOVA test, followed by Dunnet $\mathrm{T}^{3}$ post-hocs test $(p \leq 0.05)$

contrary, Ali et al. (2003) have reported that cornsilk did not show any diuretic action when given alone but yet it did increase sodium, potassium and chloride contents in the urine excreted. These report seemed to be opposite to the present result discovered. Opportunely, Maksimovic et al. (2004) have reported the urine excretion resulted from cornsilk administration to rats. Compared to other studies by Arafat et al. (2008) and Nedi et al. (2004), potassium level in all groups was enormously high. It was reported that normal urine electrolytes excreted during $24 \mathrm{~h}$ for $\mathrm{Na}^{+}$ and $\mathrm{K}^{+}$are 200 and $150 \mathrm{mmol} / \mathrm{l}$, respectively (Johnson 2007). However it has also been mentioned, there will be distinction of contents due to diverse strain of animal, supplier, feed and housing condition used. Hence, the atypical value of $\mathrm{K}^{+}$excretion in this study may be due to the diet given to the animal.

Interestingly, the insignificant $\mathrm{K}^{+}$value found between $\mathrm{AEC}$ and distilled water indicates that $\mathrm{AEC}$ has demonstrated a possible effect as potassium sparing diuretics. Since, AEC did not alter the $\mathrm{K}^{+}$exretion in the urine while elevated diuresis. However, a detailed study has to be performed by in vivo test to confirm the potassium diuretics effect (Alarcon-Alonso et al. 2012). In addition, AEC also do not caused over stimulation of renin angiotensin aldosterone system (RAAS) as happened with acute administration of furosemide due to the associated kaliuresis (Cataliotti et al. 2004). The increased of saliuretic index for $\mathrm{Na}^{+}$can be observed in all AEC though it was not significant. But 
the increment was obviously observed at doses of 500 , 600 and $800 \mathrm{mg} / \mathrm{kg}$. This result possibly indicated that the inhibition of $\mathrm{Na}^{+}$resorption in nephron occured and causes the diuresis (Ratnasooriya et al. 2009). On the other part, the $\mathrm{NA}^{+} / \mathrm{Cl}^{-}$ratio of AEC doses at 600 and $700 \mathrm{mg} /$ $\mathrm{kg}$ showed marked increased. But this result do not give final conclusion for AEC to act like hydrochlorothiazide diuretics as the $\mathrm{Na}^{+} / \mathrm{Cl}^{-}$ratio do not increased in line with the increased of AEC doses.

Though the $\mathrm{pH}$ value among doses did not have significant differences, the trend of alkalization can be observed as the doses increased. Concurrence to Fjellstedt et al. (2001), alkalization of urine enhanced the solubility of cystine, as well as neutralising the acid level in the urine. The present result also showed no alteration of osmolality level. This indicates that, AEC did not alter the impaired basal secretion of ADH (anti diuretic hormone) nor lessened the sensitivity of uniferous tubule that influences the $\mathrm{ADH}$ secretion (Osario \& Teitelbaum 2002).

Likely, the thiazide diuretics inhibit the $\mathrm{Na}^{+} / \mathrm{Cl}^{-}$ symporter in the distal convulated tubule by competing the $\mathrm{Cl}^{-}$site and increasing the excretion of $\mathrm{Na}^{+}$and $\mathrm{Cl}^{-}$(Rang et al. 2007). Meanwhile, loop diuretics elevates urine excretion and $\mathrm{Na}^{+}$by inhibiting $\mathrm{Na}^{+} / \mathrm{K}^{+} / 2 \mathrm{Cl}^{-}$symporter in the thick ascending limb of the loop of Henle (Jackson 1996). Loop diuretics like furosemide increased the excretion of $\mathrm{Na}^{+}, \mathrm{K}^{+}$and $\mathrm{Cl}^{-}$. Nevertheless there are many ways for diuresis to occur. Likewise, herbs that contain of high sodium or potassium (Hook et al. 1993) helps to promote diuresis by inhibit the reabsorption of renal tubular. In contrast to the present study, sodium content of AEC is very low but somehow it significantly increased urine excretion at dose 600 to $800 \mathrm{mg} / \mathrm{kg}$.

The other diuresis mechanism is by arousing the thirst centre in the hypothalamus to boost the fluid intake (Neuman 2002). Besides that, inhibition of ATPase activity can impact the $\mathrm{Na}^{+} / \mathrm{K}^{+}$concentration in the epithelial cells of nephron tubular segment which enhance the diuretic activity (Mezesova et al. 2010). The $\mathrm{Na}^{+} / \mathrm{K}^{+}$ ratio of AEC do have a dose dependant manner but it was not significant. Moreover, particular phytochemicals act as vasoconstrictors agent and aid the release of renal prostaglandins (Gasparotto Junior et al. 2009). When vasoconstrictors are released, prostaglandins amend their effects on kidney by causing compensatory vasodilatation (Rang et al. 2007).

In the previous study, a various phytochemicals was identified in cornsilk (Solihah \& Wan Rosli 2012). The component found were saponin, phlobatannins, tannin, flavonoid, phenols, alkaloid and glycosides. These components possibly provoked the diuresis. There are various plants exhibited diuretic activity due to its components. The ursolic acid from wild African olive leaves has demonstrated diuretic activity. Freitas et al. (2011) has suggested this compound also induced diuresis in Palicourea coriacea. Moreover, catechin a flavanoid group has been reported to promote urine excretion in human (Donovan et al. 2002). Meanwhile quercetin influenced the diuretic activity of Hibiscus sabdariffa (Alarcon-Alonso et al. 2012).

Apart from that, phlobatannins found in Cnidoscolus aconitifolius has been suggested to be responsible for the diuretic action of the plant (Awoyinka 2007). Hence, there are many compounds contained in crude AEC which could possibly provoke diuresis. It is possible that it works individually or synergistically with flavonoids, saponin or organic acid (Sadki et al. 2010). At this point, there is no scientific evidence associated the active compounds responsible for diuretic activity in cornsilk. Therefore, further study need to be done to examine the particular compound which responsible to this activity.

Since we do not examine the explicitly mechanism of the diuresis in this study, we can only suggest the possible mechanism happened during diuresis of AEC. The diuretic action of AEC probably was implicated by arousing the thirst centre of hypothalamus due to the action of compound presence in the AEC. These compounds probably act individually or synergistically. This mechanism probably has influenced the water intake of those rats treated with AEC doses, since all rats have access to water during this investigation. Another mechanism might involve with this diuretic activity is the action of AEC as potassium sparing diuretics. However, detail study needs to be performed in order to investigate the particular mechanism.

Another observation is evaluated during the study that is specifically on the effective dose of AEC (Figure 2). The plateau effect of the extract may be to the effect of different features of compound action or due to the toxic effect which was noticeable at higher doses (Sangma et al. 2010). This trend most probably related to the various compounds composed in the extract, since there maybe intervention among compound as the doses of extract increased (Nedi et al.2004). The pharmacological effective dose of diuresis study was unavailable. Therefore, a comprehensive comparison is unable to be discussed.

During repeated oral administration of AEC over 5 days, there are no statistical differences found in all parameters studied including cumulative urine, $\mathrm{pH}$, osmolality, $\mathrm{Na}^{+}, \mathrm{K}^{+}$and $\mathrm{Cl}^{-}$with respect to day 1 of oral administration. In other investigation reported by Gasparotto Junior et al. (2011), the electrolyte content of $\mathrm{Na}^{+}$and $\mathrm{K}^{+}$increased although there was no significant value found during day 1,5,6 and 7 after administration of Tropaeolum majus extract. Other than that, Kazama et al. (2012) also signified that, administration of ethanol extract of Pereskia grandifolia produced noteworthy increased of urine and sodium content over 7 days.

On the other part, Lahlou et al. (2007) reported that tansy (Tanacetum vulgare) and caraway (Carum carvi) extracts significantly increased the urine excretion from day 1 to day 5 and then it became unwavering until day 8 . In addition, the authors found that $\mathrm{Na}^{+}$excretion at day 2 to 3 was unchanged when compared to day 1 . However, later the $\mathrm{Na}^{+}$level significantly increased throughout the study period. Contrarily, the $\mathrm{K}^{+}$excretion of tansy extract statistically increased throughout 8 days of repeated 
administration. While caraway extract had no changed on $\mathrm{K}^{+}$excretion throughout day 2 to 8 , compared to day 1 of administration. Besides that, during the prolonged study for five days there was no such acute sign of toxicity effect was observed, except the presence of slightly soft stool during treatment of CAE at doses of 600,700 and $800 \mathrm{mg} / \mathrm{kg}$ and at 40 and $60 \mathrm{mg} / \mathrm{kg}$ during CME treatments at day 4 and 5. Other than that, Mirza et al. (2003) have reported that principal constituent of this plant is not harmless. Besides, it has been proven with the histopathological study on liver and kidney of rats that had been administered with cornsilk extract is safe to be consumed (Mirza et al. 2004).

\section{CONCLUSION}

The study illustrates that Malaysian cornsilk have shown marked diuretic activity. Then, the $\mathrm{ED}_{50}$ of $\mathrm{AEC}$ is observed at $454.10 \mathrm{mg} / \mathrm{kg}$. Beneficially, this extract has shown an interesting potassium sparing effect. It appears that Malaysian cornsilk can be used as an alternative natural diuretic agent as it promotes diuresis and does not affecting osmolality of urine.

\section{ACKNOWLEDGMENTS}

The authors would like to thank Universiti Sains Malaysia for the USM Research University Grant's allocation (1001/ PPSK/813057), Unit Pengurusan Makmal Sains and ARASC for the facilities provided.

\section{REFERENCES}

Ali, M., Wahbi, S., Twaij, H. \& Al-Badr, A. 2003. Tribulus terrestris: Preliminary study of its diuretic and contractile effects and complication with Zea mays. Journal of Ethnopharmacology 85: 257-260.

Alarćon-Alonso, J., Zamilpa,A., Aguilar, F.A., Herrera-Ruiz, M., Tortoriello, J. \& Jimenez-Ferrer, E. 2012. Pharmacological characterization of the diuretic effect of Hibiscus sabdariffa Linn (Malvaceae) extract. Journal of Ethnopharmacology 139: 751-756.

Arafat, O.M., Tham, S.Y., Sadikun, A., Zhari, I., Haughton, P.J. \& Asmawi, M.Z. 2008. Studies on diuretic and hypourecemic effects of Orthosiphon stamineus methanol extracts in rats. Journal of Ethnopharmacology 118: 354-360.

Awoyinka, O.A., Balogun, I.A. \& Ogunnowo, A.A. 2007. Phytochemical screening and in vitro bioactivity of Cnidoscolus aconitifolius (Euphorbiaceae). Journal of Medicinal Plants Research 1(3): 6365.

Bobryshev, N.E. 1962. Corn- a medicinal plant. Kukuruza 9: 59.

Buhner, S.H. 2007. The Natural Testosterone Plan; for Sexual Health and Energy. Vermont: Healing Arts Press. http://www. HealingArtsPress.com. p. 77-78.

Cataliotti, A., Boerrigter, G., Costello-Borrigter, L.C., Schirger, J.A., Tsuruda, T., Heublin, D.M., Chen, H.H., Malatino, L.S. \& Burnett Jr, J.A. 2004. Brain natriuretic peptide enhances renal actions of furosemide and suppresses furosemideinduced aldosterone activation in activation heart failure. Circulation 109: 1680-1685

Donovan, J.L., Karakas, S.K., German, J.B . \& Waterhouse, A.L. 2002. Urinary excretion of catechin metabolites by human subjects after red wine consumption. The British Journal of Nutrition 87: 31-37.

Ebrahimzadeh, M.A., Pourmorad, F. \& Hafezi, S. 2008. Antioxidant activities of Iranian corn silk. Turky Journal of Biology 32: 43-49.

Eisyok, D., Otles, S. \& Akcicek, E. 2004. Herbs as a food source in Turkey. Asian Pacific Journal of Cancer Prevention 5: 334-339.

El-Ghorab,A., El-Massary, K.F. \& Shibamoto, K. 2007. Chemical composition of volatile extract and antioxidant activities of the volatile and non-volatile extracts of Egyptian corn silk (Zea mays L.). Journal of Agricultural and Food Chemistry 55: 9124-9127.

Eman, A.A. 2011. Evaluation of antioxidant and antibacterial activities of Egyptian Maydis stigma (Zea mays hairs) rich of bioactive constituents. Journal of American Science 7(4): 726-729.

Feitas, P.C.M., Pucci, L.L., Vieira, M.S., Lino Jr, R.S., Oliveira, C.M.A., Cunha, L.C., Paula, J.R. \& Valarades, M.C. 2011 Diuretic activity and acute oral activity of Palicourea coriacea (Cham) K Schum. Journal of Ethnopharmacology 134: 501-503.

Fjellstedt, E., Denneberg, T., Jeppsson, J.O. \& Tiselius, H.G 2001. A comparison of the effects of potassium citrate and sodium bicarbonate in the alkalinisation of urine in homozygous cystunaria. Urology Research 29: 295-302.

Foote, J. \& Cohen, B. 1998. Medicinal herb use and the renal patient. Journal of Renal Nutrition 8: 40-42.

Gasparotto Junior, A., Gasparotto, F.M., Boffo, M.A., Lourenco, E.L.B., Stefanello, M.E.A., Salvador, M.J., da Silva-Santos, J.E., Mrques, M.C.A. \& Kassuya, C.A.L. 2011. Diuretic and potassium-sparing effect of iso-quercitrin-An active flavonoid of Tropaeolum majus L. Journal of Ethnopharmacology 134: 210-215.

Gasparotto Junior, A., Boffo, M.A., Lourenco, E.L., Stefanello, M.E., Kassuya, C.A.L. \& Marques, M.C. 2009. Natriuretic and diuretic effects of Tropaelum majus (Tropaelaceae) in rats. Journal of Ethnopharmacology 122: 517-522.

Hook, I., McGee, A. \& Henman, M. 1993. Evaluation of dandelion for diuretic activity and variation in potassium content. Pharmaceutical Biology 31(1): 29-34.

Jackson, E.K. 1996. Drugs affecting renal and cardiovascular function. In Goodman and Gilman's the Pharmacological Basis of Therapeutics. 9th ed., edited by Hardman, J.C., Gilman,A.G. \& Limbird, L.E. New York: Pergammon Press. pp. 685-713.

Johnson, M.D. 2007. The rat. In Animal Models in Toxicology. 2nd ed., edited by Gad, S.C. New York: Taylor and Francis Group. pp. 150-171.

Kazama, C.C., Uchida, D.T., Kanzi, K.N., de Souza, P., Crestani, S., Gasporotto Junior, A. \& Laverdo Junior, A. 2012. Involvement of arginine-vasopressin in the diuretic and hypotensive effects of Pereskia grandifolia Haw. (Cactaceae) Journal of Ethnopharmacology 144: 86-93.

Lahlou, S., Tahraoui, A., Israili, Z. \& Lyoussi, B. 2007. Diuretic activity of aqueous extracts of Carum carvi and Tanacetum vulgae in normal rats. Journal of Ethnopharmacology 110: 458-463.

Liu, J., Wang, C., Wang, Z., Zhang, C., Lu, S. \& Liu, J. 2011 The antioxidant and free-radical scavenging activities of the extract and fraction from cornsilk (Zea mays L.) and related flavone glycosides. Food Chemistry 126(1): 261-269. 
Maksimovic,Z., Malencic, D. \& Kovacevic, N. 2005. Polyphenol contents and antioxidant activity of Maydis stigma extracts. Bioresource Technology 96: 873-877.

Maksimovic, Z., Dobric, S., Kovacevic, N. \& Milovanovic, Z. 2004. Diuretic activity of Maydis stigma extract in rats. Pharmazie 59: 193-197.

Mezesova, L., Bartekova, M., Javorkova, V., Vlkovicova, L., Breier, A. \& Vrbjar, N. 2010. Effect of quercitin on kinetic properties of renal $\mathrm{Na}, \mathrm{K}$-ATPasa in normotensive and hypertensive rats. Journal of Physiology and Pharmacology 61: 593-598.

Mirza, M., Zahra, Y., Khatoon, N. \& Qadri, R.B. 2004. Histophatological studies of some indigenous diuretic medicinal plants in rats. Pakistan Journal of Biological Sciences 7(11): 1847-1850.

Mirza, M., Mahboob, A.K., Zahra, Y., Tahira, B.S. \& Qadri, R.B. 2003. Physio-chemical studies of indigenous diuretic medicinal plants. Pakistan Journal of Pharmacology 20: 9-16.

Nedi, T., Mekonnen, N. \& Urga, K. 2004. Diuretic effect of crude extracts of Carissa edulis in rats. Journal of Ethnopharmacology 95: 57-61.

Neuman, M. 2002. Metabolic effects and drug interactions provoked by certain vegetables: Grapefruit, St. John's wort and garlic. Presse Médicale 31: 1416-1420.

Osorio, F.V. \& Teitelbaum, I. 2002. Mechanism of defective hydroosmotic response in chronic renal failure. Journal of Nephrology 10: 232-239.

Rang, H.P., Dale, M.M., Ritter, J.M. \& Flower, R.J. 2007. Rang and Dale's Pharmacology. 6th ed. Philadelphia: Churchill Livingstone Elsevier. p. 374

Ratnasooriya, W.D., Fernando, T.S.P. \& Ranathunga, R.A.R. 2009. Diuretic activity of Sri Lankan black tea (Camellia sinensis L) in rats. Pharmacognosy Research 1: 4-10.
Sadki, C., Hacht, B., Souliman, A. \& Atmani, F. 2010. Acute diuretic activity of aqueous Erica multiflora flowers and Cyanodon dactylon rhizomes extract in rats. Journal of Ethnopharmacology 128: 352-356.

Sangma, T.K., Meitei, U.D., Sanjebam, R. \& Khumbongmayon, S. 2010. Diuretic property of aqueous extract of leaves of Mimosa pudica Linn. on experimental albino rats. Journal of Natural Products 3: 172-178.

Solihah, M.A. \& Wan Rosli, W.I. 2012. Phytochemicals screening and total phenolic contents of Malaysian Zea mays hair extracts. International Food Research Journal 19(4): 15331538.

Steenkamp, V. 2003. Phytomedicine for the prostate. Fitoterapia 74: $545-552$.

Wright, W.I., Van-Buren, L., Kroner, C.I. \& Koning, M.M.G. 2007. Herbal medicines as diuretic: A review of scientific evidence. Journal of Ethnopharmacology 114: 1-31.

Xin, Z., Edward, E.C., Weiqun, W. \& Rajeshekar, C.B. 2006. Does organic production enhance phytochemical content of fruit and vegetables? Current knowledge and prospects for research. Hort Technology 16(3): 449-456.

Nutrition Programme, School of Health Sciences

Universiti Sains Malaysia

11800 Penang

Malaysia

*Corresponding author; email: rosliishak@gmail.com

Received: 1 June 2014

Accepted: 1 April 2015 